DZIENNKARSTWO 9

DOI: $10.19195 / 2082-8322.9 .7$

Dorota Dyksik

ORCID: 0000-0001-9279-8678

Uniwersytet Wrocławski

\title{
Od cytryn po nowe fryzury i dragi, czyli o tym, jak prowadzić komunikację o nowotworach w czasach nieuwagi
}

\begin{abstract}
Rozpoznanie na kartach, podobnie jak na kartach gorączkowych, wiszących przy łóżku, pisaliśmy zawsze po łacinie. Słowo nowotwór nigdy nie było wymieniane z nazwy. Zastępowała je jedna litera (i nawet teraz, gdy to piszę, pióro moje cofa się przed jej wymienieniem). Podobnie przy łóżku chorego, podczas wizyty, lekarze rozmawiali ze sobą głosem ściszonym, unikając drastycznych sformułowań, gęsto szpikując zdania żargonem łacińskim, by chory nie wszystko dosłownie przyjął, nie przestraszył się, by oszczędzić mu zgryzoty i lęku .
\end{abstract}

Andrzej Szczeklik, Kore

\section{Wstęp}

Nowotwór, zgodnie z zaproponowaną 50 lat temu przez R.A. Willisa, brytyjskiego onkologa, a funkcjonującą do dzisiaj definicją, „to nieprawidłowa tkanka, która rozrasta się w nadmiarze i w sposób nieskoordynowany $\mathrm{z}$ tkankami prawidłowymi" 2 . Znamion tej siejącej współcześnie strach choroby można jednak doszukiwać się na długo przed rozpoczęciem naszej ery. Hipokrates (460-370 rok p.n.e.), uznawany za

1 A. Szczeklik, Kore. O chorych, chorobach i poszukiwaniu duszy medycyny, Kraków 2007.

2 R.A. Willis, Spread of Tumors in the Human Body, London 1952, s. 167. 
ojca medycyny, jako pierwszy mianem „rak” określił wszystkie rozrosty złośliwe, które można było zaobserwować u człowieka. Z kolei Paweł z Eginy (około 625-690 rok) podawał, że „rak powstaje w każdej części ciała i przytwierdza się tak uporczywie jak krab”3. Można wyróżnić wiele postaci raka — skóry, płuc, żołądka, szyjki macicy, różne odmiany białaczki i tak dalej. Jednak wszystkie mają wiele wspólnego, przede wszystkim na poziomie komórkowym: „W przypadku każdej z nich komórki zyskały tę samą cechę - pęd do niekontrolowanego, patologicznego podziału”4.

Historia raka to historie pokoleń, które od czterech tysięcy lat toczą walkę z nowotworami. W pewnym sensie jest to historia wojny, „w której przeciwnik charakteryzuje się bezpostaciowością, ponadczasowością i wszechobecnością"5. Są zwycięstwa i porażki, wiele przeprowadzonych kampanii, programów, wielu bohaterów, a także, co nieuniknione, „rannych, potępionych, zapomnianych i zmarłych”. W zdrowiu publicznym i higienie zaszły zmiany, które przyczyniły się do diametralnej przemiany wizerunku chorób, zwłaszcza w Ameryce (choroby zakaźne, które dziesiątkowały całe dzielnice, znikały między innymi dzięki poprawie warunków sanitarnych ${ }^{7}$ ). „Choroba” znalazła się na trzecim miejscu listy zmartwień po „pieniądzach" i „wychowywaniu dzieci" 8 . Nic jednak nie wskazuje na to, by rak zamierzał dać się pokonać - ani osiągnięciom nauki, ani wzrostowi świadomości społecznej. Wręcz przeciwnie: liczne badania wskazują, że do 2030 roku zachorowalność na raka na świecie zwiększy się aż o 75\%. Według prognoz Światowej Organizacji Zdrowia, opublikowanych na łamach czasopisma „Lancet Onkology”, w 2030 roku w 184 krajach na nowotwory będzie chorować 22,2 miliona ludzi. Zdaniem ekspertów główną przyczyną wzrostu zachorowań jest starzenie się społeczeństw oraz niezdrowy tryb życia, między innymi palenie papierosów, nieracjonalne nawyki żywieniowe. W krajach rozwiniętych, w tym również w Polsce, najczęściej występują nowotwory płuc, jelita grubego, prostaty u mężczyzn i piersi u kobiet ${ }^{9}$. Prognozy na rok 2030 wskazują również na wzrost znaczenia działań prewencyjnych promujących zachowania prozdrowotne społeczeństw. Obraz epidemiologiczny pozwala bowiem sądzić, że onkolodzy nie są w stanie sami wygrać walki $\mathrm{z}$ rakiem ${ }^{10}$. Stąd od lat mamy do czynienia nie tylko z programami wczesnej diagno-

3 R. Klimek, J.M. Madej, A. Sieroń, Rak - nowotwory a choroby nowotworowe, Kraków 2006.

4 S. Mukherjee, Cesarz wszech chorób. Biografia raka, Wołowiec 2013, s. 39.

5 Ibidem, s. 14.

6 Ibidem.

7 E. Sydenstricker, Health in the New Deal, „Annals of the American Academy of Political and Social Science" 176, 1934, s. 131-137, za: S. Mukherjee, op. cit., s. 39.

8 H.J. Gans, The Levittowners. Ways of Life and Politics in a New Suburban Community, New York 2007, s. 234.

${ }^{9}$ http://www.thelancet.com/journals/lanonc/article/PIIS1470-2045(12)70211-5/fulltext (dostęp: 10 czerwca 2017).

10 W. Zatoński, Epidemiologia chorób nowotworowych i skuteczność walki z rakiem w Polsce, http:// ac.els-cdn.com/S1507136703704866/1-s2.0-S1507136703704866-main.pdf?_tid=e0f9f028-4f65-11e7-9433-00000aacb35f\&acdnat=1497268644_6ea600ff0c765a6cc3e89b20c407366e (dostęp: 12 czerwca 2017). 
styki, ale również z wieloma działaniami medialnymi, które służyć mają promowaniu zdrowia i zdrowego stylu życia. Jednym z tych narzędzi, a zarazem uznawanym za prymarne, jest reklama społeczna, której celem jest wywołanie społecznie pożądanych postaw i zachowań ${ }^{11}$. Niestety wciąż jest za mało programów i kampanii dotyczących samych nowotworów, zwłaszcza nowotworów kobiecych. Autorzy książki Kobieta i (b) rak. Wizerunki raka piersi $w$ kulturze wskazują na problem raka piersi w polskich mediach i kulturze - temat ten jest w nich prawie nieobecny.

Właściwie dopiero od paru lat o chorobach nowotworowych zaczyna się mówić otwarcie, bez fałszywego wstydu, bez lęku przed odrzuceniem czy napiętnowaniem. Pomimo coraz liczniej wypowiadających się w różnych mediach kobiet chorujących na raka piersi to jeszcze ciągle za mało, by powstał z tego jakiś złożony, acz spójny system oddziaływań na opinię publiczną, na instytucje publiczne, na politykę społeczną państwa itp. ${ }^{12}$

Tym samym analizie zostały poddane współczesne, niestandardowe formy reklam społecznych nawiązujące do tematu raka piersi. Są to zarówno polskie, jak i zagraniczne kampanie, wskazujące na sposoby wczesnej diagnostyki oraz obalające mity i przesądy związane z nowotworami. Ich charakterystyka pozwoli odpowiedzieć na pytanie o nową jakość i użyteczność stosowanych narzędzi - czy zmieniły coś w funkcjonowaniu reklamy społecznej, czy też stały się kolejną płaszczyzną do komunikacji, jak plakat, prasa, billboard, radio czy telewizja? Wymienione pytania pojawiają się w kontekście zmian w obszarze teorii komunikacji, ale stanowią również istotny wstęp do dyskusji nad zmianami komunikacyjnymi w obrębie zagadnienia, jakim jest nowotwór.

\section{Reklama społeczna w czasach nieuwagi}

Bezustanny konsumpcjonizm i rozkwit cywilizacyjny doprowadziły do wielu patologii, w tym wzrostu liczby zagrożeń i pejoratywnych postaw. Aby temu zapobiec, potrzebny był środek, który pozwoliłby uwrażliwić ludzi na problemy społeczne, skłonić do zmiany postaw. Za idealne narzędzie uznano reklamę, która wychodząc poza obszar materialny oraz służąc dobru ogółu, zyskała miano reklamy społecznej. Jednak w ostatnich latach reklama ta przeszła ewolucje, które diametralnie zmieniły jej oblicze. Dzisiaj, wraz z natłokiem informacji i wzrostem liczby przekazów reklamowych, maleje uwaga odbiorców, a co za tym idzie - spada także wpływ komunikatów mających na celu uzmysłowienie istniejących problemów społecznych oraz wezwanie do określonych działań prospołecznych. Okazuje się, że podobną tendencję można było zaobserwować już w osiemnastowiecznej Anglii — w 1759 roku doktor

11 D. Maison, N. Maliszewski, Co to jest reklama społeczna, [w:] Propaganda dobrych serc, czyli pierwszy tom o reklamie społecznej, red. D. Maison, P. Wasilewski, Kraków 2008, s. 9.

12 Kobieta i (b)rak. Wizerunki raka piersi w kulturze, red. E. Zierkiewicz, A. Łysak, Wrocław 2007. 
Johnson napisał: „Obecnie mamy do czynienia z tak wieloma reklamami, że czytamy je nieuważnie"13.

Przyczyn takiego stanu rzeczy można szukać w charakterze reklam społecznych realizowanych w Polsce od lat dziewięćdziesiątych. Rafał Drozdowski i Marek Krajewski w publikacji zatytułowanej Reklama w Polsce - grzechy i możliwości $i^{14}$ wskazują na błędy kampanii społecznych, które były spowodowane takimi czynnikami, jak: niski poziom zaufania społeczeństwa w stosunku do reklam, które kojarzyły się z PRL-owską propagandą; intuicyjne podejście do tematu; brak wskazywania sposobów rozwiązania problemu, epatowanie negatywnymi emocjami czy niewystarczające środki na realizację kampanii.

Podobne scenariusze w reklamie społecznej dotyczyły chorób nowotworowych. Często kampanie te miały charakter informacyjny lub mówiły o sprawach, które wywołują lęk i o których większość ludzi chciałaby zapomnieć. Jedną z nich jest kampania dotycząca raka piersi, przeprowadzona w latach 1999-2000. Kampania Możemy zdązyć przed rakiem została zainicjowana przez fundację Porozumienie bez Barier, a za jej projekt odpowiedzialny był Andrzej Pągowski, prekursor reklamy społecznej w Polsce, grafik artysta. W kampanii zostały wykorzystane trzy hasła reklamowe: „Z powodu raka piersi co 10 lat znika z mapy Polski 50-tysięczne miasto kobiet”, „Rak wielkości 1-2 cm jest całkowicie wyleczalny” oraz „W Polsce 75\% kobiet $\mathrm{z}$ rakiem piersi trafia do szpitala zbyt późno". Plakaty i billboardy pozbawione były elementów graficznych, a sama kampania miała charakter informacyjny, zwracając tym samym uwagę na istnienie problemu częstotliwości występowania raka piersi wśród Polek ${ }^{15}$. Kolejnym przykładem reklamy jest kampania Chronię życie przed rakiem szyjki macicy, która rozpoczyna się komunikatem „Codziennie pięć kobiet umiera na raka szyjki macicy”. W następnych częściach spotu ukazują się dwie postaci. Mężczyzna, który mówi: „Miesiąc temu zmarła moja żona, była dla mnie wszystkim”, następnie kobieta: „Stwierdzono u mnie piątą grupę cytologiczną, nigdy wcześniej nie robiłam cytologii, mam raka w zaawansowanym stadium". Na końcu pojawia się zapłakana dziewczynka z komunikatem: „Nie chcę, żeby mama umarła" ${ }^{\prime 6}$. Przykłady tych dwóch pierwszych w Polsce kampanii dotyczących chorób nowotworowych wskazują na wykorzystanie mechanizmów, które mają za zadanie działać na wrażliwość odbiorcy, wywołać określone reakcje i emocje. Z jednej strony mamy do czynienia z niepokojącymi statystykami, z drugiej zaś z przygnębioną ko-

13 A. Ingram, The challenge of ad avoidance, „Admap” 472, maj 2006, cyt. za: N. Hatalska, Nie tylko wielka piatka, czyli ambient media i marketing szeptany jako alternatywne formy komunikacji, [w:] Reklama i PR na rozdrożu?, red. H. Mruk, Poznań 2008, s. 51-61.

14 R. Drozdowski, M. Krajewski, Reklama społeczna w Polsce - grzechy i możliwości, Akademia Europejska - materiały szkoleniowe, Bielsko-Biała 1998, s. 5.

15 E. Antczak, Kampanie społeczne Fundacji „Porozumienie bez barier”, [w:] Propaganda dobrych serc..., s. 107-109.

16 https://www.youtube.com/watch?v=TPPhBRlWgUs (dostęp: 14 czerwca 2017). 
bietą i płaczącym dzieckiem. Tak w skrócie można opisać środki wyrazu stosowane w latach dziewięćdziesiątych w polskich kampaniach społecznych.

Kolejny problem dotyczy stosunku użytkowników do reklamy jako takiej, co może wpływać na odbiór poszczególnych komunikatów. Ostatnie badania wykazują wyraźny trend spadkowy dotyczący zarówno zaciekawienia reklamą, jak i stosunku do niej: zdecydowana większość Polaków (86\%) nie lubi reklam, a tylko co ósmy (13\%) ma do nich pozytywny stosunek. Największa grupa respondentów (48\%) czuje się przymuszana do oglądania lub wysłuchiwania reklam, mimo że za nimi nie przepada, a blisko dwie piąte (38\%) nie lubi reklam, dlatego też unika ich oglądania i słuchania ${ }^{17}$.

Mimo dynamicznego rozwoju reklamy w Polsce, prowadzonych badań, kampanii realizowanych konsekwentnie i długofalowo, coraz częściej można zauważyć, że staje się ona „naturalnym tłem, szumem, którego nie słychać, ale który ani nie drażni, ani nie zachwyca - po prostu nie zwraca się na niego uwagi""18. Taka teza w odniesieniu do potrzeby komunikacji na temat zdrowia, gdzie zarówno mass media, jak i sama reklama mają do spełnienia istotne funkcje, stawia przed nadawcami kolejne wyzwania. Wielowymiarowy charakter zmian w obrębie reklamy inspiruje do podjęcia rozważań na temat „Zabiegów propagandowych, technik wywierania wpływu, perswazji i nakłaniania”, co również stanowi czynnik zmienny w czasie, jeżeli brane pod uwagę będą takie elementy, jak „zwiększenie świadomości istnienia tych zabiegów, uodpornienie na nie czy etyka prowadzonych działań” ${ }^{19}$. Stąd przyjęty temat wymusza podjęcie prób poznania skali i znaczenia reform w obrębie samej reklamy.

\section{Rak piersi w niestandardowych reklamach społecznych}

Powstałe zmiany wymuszają na twórcach reklam dopasowanie się do nowej rzeczywistości, w której, by komunikat o charakterze społecznym mógł trafić do odbiorcy, zmienić jego nastawienie do poruszanego zagadnienia, wpłynąć na jego zachowanie, konieczne jest porzucenie dotychczasowych praktyk i skupienie się na niestandardowych narzędziach pozwalających zaskoczyć i, co najważniejsze, również zaangażować odbiorcę - obojętnego dzisiaj na tradycyjne nośniki przekazu. W ten sposób powstało kolejne narzędzie komunikacji - tak zwane ambient media. Termin ten pojawił się po raz pierwszy w zachodniej prasie branżowej w $1997 \mathrm{roku}^{20}$. Ambient

17 http://www.cbos.pl/SPISKOM.POL/2011/K_016_11.PDF (dostęp: 30 listopada 2016).

18 M. Dołhasz, Reklama ambientowa - nowa forma komunikacji marketingowej przedsiębiorstw, „Zeszyty Naukowe Uniwersytetu Szczecińskiego” 559, 2009, s. 422.

19 J. Jakubowski, Nowe media - nowa reklama społeczna?, http://www.academia.edu/12154395/ Nowe_media_nowa_reklama_społeczna559 (dostęp: 25 listopada 2016).

${ }^{20}$ N. Hatalska, Cząstki przyciaggania: jak budować niestandardowe kampanie reklamowe, Gliwice 2014, s. 195.

Dziennikarstwo i Media 9, 2018

(C) for this edition by CNS 
w języku angielskim oznacza „otaczający”. Webster's Dictionary przypisuje słowu ambient znaczenie „obejmujący, okrążający ze wszystkich stron, rozpościerający się”. $\mathrm{Z}$ kolei Cambridge Advanced Learner's Dictionary definiuje ambient jako „występujący w otaczającym terenie"21. W Polsce bardzo często stosowany jest zamiennie termin „niestandardowe formy komunikacji”, lecz zarówno jeden, jak i drugi sprawiają nadawcom reklam oraz badaczom wiele kłopotów terminologicznych. Pytanie „czym są niestandardowe formy komunikacji” jest pytaniem naturalnym, owo pojęcie jest bowiem niezwykle szerokie ${ }^{22}$. R. Samborski pisze, że ambient „to sposób podejścia do reklamy. To myślenie. To ta sama reklama, tylko bardziej otwarta na odbiorcę, do którego przemawia tam, gdzie on mieszka, je, pracuje, chodzi, bawi się, żyje" ${ }^{23}$. Zdaniem D. Trzeciaka ambientem można określić działania związane z opracowywaniem, planowaniem i wdrażaniem niestandardowych kampanii marketingowych wykorzystujących w otoczeniu wszystko to, co możliwe i niemożliwe, znane i niezna$n e^{24}$. Z kolei N. Hatalska dokonuje interpretacji terminu, zwracając uwagę na takie elementy składowe, jak:

— obecność poza tradycyjnymi mediami — reklama głównie w przestrzeni miejskiej, lecz nie na standardowych nośnikach,

- obecność w tradycyjnych mediach (radio, prasa, telewizja, Internet), ale w inny niż powszechnie przyjęty sposób.

Do niestandardowych form reklamy zaliczane są również działania, które korzystają z:

— zjawiska sieci społecznych (marketing wirusowy, marketing szeptany),

- nowych technologii ${ }^{25}$.

Poza kwestiami terminologicznymi niestandardowe formy komunikacji wiążą się również z innymi problemami. Jednym z nich jest kwestia zasięgu. Jak twierdzi N. Hatalska, w odróżnieniu od tradycyjnych mediów komunikaty o charakterze niestandardowym powinny zwracać na siebie uwagę, budować interakcje oraz angażować. Wyłącznie gdy akcja jest udana, może nastąpić tak zwany efekt zwielokrotnienia, gdy informacja o akcji rozprzestrzenia się wśród odbiorców za pośrednictwem mediów społecznościowych, a następnie trafia do mediów tradycyjnych ${ }^{26}$. Innym problemem jest ich „jednorazowość”. Siła ambient mediów opiera się na elementach zaskoczenia, innowacji oraz niespodzianki. Z tym z kolei wiążą się dodatkowe problemy w postaci oszacowania kosztów oraz badania skuteczności takich działań.

21 Ł. Koszuba, Zastosowanie ambient mediów dla celów promocyjnych na przykładzie wybranych kampanii marketingowych $w$ Polsce, https://www.slideshare.net/ukaszKaszuba/ambient-media-w-polsce, s. 24.

22 N. Hatalska, Czastki przyciagania..., s. 17.

23 R. Samborski, Ambient - myślenie o reklamie, „Brief” 52, 2001, www.brief.pl.

24 I. Zbonikowska, Ambientowy rynek 02.06.2009, www.oohmagazine.pl.

25 N. Hatalska, Czastki przyciagania..., s. 17-18.

${ }^{26}$ Ibidem, s. 18. 
Pomimo tych wad, istnieje wiele badań, które wskazują, że w połączeniu z tradycyjnymi środkami przekazu ambient media znacząco podnoszą zauważalność kampanii. Skuteczność opiera się przede wszystkim na zaskoczeniu klienta oraz pojawieniu się w miejscu i czasie, których odbiorca najmniej się spodziewa ${ }^{27}$, na przykład na toaletach, umywalkach, tramwajach, przystankach, podłodze w sklepie, na trawniku. Ostatnie lata sprawiły, że nasza zdolność do zapamiętywania reklam telewizyjnych spadła aż o 70\%. Ta niekorzystna dla nadawców reklam sytuacja to wynik pracy mózgu, w którym znajdują się naturalne mechanizmy (tak zwane filtrowanie ) zapobiegające przeładowaniu pamięci przez napływające informacje ${ }^{28}$. Kolejnym mechanizmem jest czas. W przeciwieństwie do reklamy w mediach tradycyjnych działania niestandardowe docierają do odbiorcy we właściwym czasie, wtedy, gdy odbiorca nic angażującego nie robi - na przykład stoi na przystanku, czeka na bagaż na lotnisku lub jedzie autobusem. Wśród badaczy reklamy istnieje przekonanie, że w sytuacji nudy podatność na komunikat i jego zauważalność jest zdecydowanie najwyższa ${ }^{29}$. Dodatkowy element charakteryzujący reklamę niestandardową to bliskość. W wypadku ambientu jest ona dosłowna. Znajduje się w najbliższym otoczeniu klienta, lecz nie osacza go, a raczej utożsamia się tematycznie z zastanym miejscem. Przewaga tej cechy opiera się na decyzjach zakupowych klientów. Okazuje się, że $70-80 \%$ decyzji zakupowych jest podejmowanych bezpośrednio przy półce sklepowej. Im bliżej znajdzie się odbiorca, tym większa szansa, że komunikat wpłynie na jego myślenie lub sposób postępowania ${ }^{30}$. Ostatnim i najważniejszym elementem ambientu jest zaangażowanie. W odniesieniu do reklam niestandardowych ma ono charakter behawioralny, czyli taki, w którym akcja reklamowa:

- wymaga od odbiorcy fizycznej mobilizacji, po to by mógł w pełni zobaczyćl zrozumieć przekaz reklamowy,

- symuluje bezpośrednie doświadczenie z produktem lub to bezpośrednie doświadczenie usposabia.

Dziś znaczna część niestandardowych komunikatów, których głównym elementem konstrukcji jest zaangażowanie, opiera się na nowych technologiach, jak również nowych mediach, za sprawą których odbiorcy angażują się w przekazywanie informacji pozostałym użytkownikom sieci ${ }^{31}$.

\subsection{Kampania Check it before it's removed organizacji Pink Ribbon Germany}

Kampania Check it before it's removed (tłum. Sprawdź, zanim zostanie usunięte) powstała z inicjatywy organizacji Pink Ribbon Germany- odpowiednika polskiej

\footnotetext{
27 N. Hatalska, Niestandardowe formy promocji, „Marketing i Rynek” 2001, nr 11, s. 7-12.

28 N. Hatalska, Czastki przyciagania..., s. 151.

29 Ibidem, s. 141.

30 Ibidem, s. 57.

31 Ibidem, s. 21.
} 
Różowej wstążki. W kampanii, która nawiązywała do potrzeby regularnych badań piersi, wzięły udział kobiety $\mathrm{w}$ różnym wieku, $\mathrm{z}$ odmiennych środowisk, o różnych zawodach, zainteresowaniach i wyglądzie. Projekt był realizowany za pośrednictwem Facebooka oraz Instagrama, a hasło (dwuznaczne, polegające na zabawie słowem) „check it before it's removed" odnosi się nie tylko do kampanii społecznej, ale również do polityki mediów społecznościowych. Na fanpage’u organizacji pojawiły się zdjęcia kobiet z odsłonięta jedną piersią i napisem „Proszę wziąć udział w naszej inicjatywie i podzielić się jednym z naszych zdjęć na Facebooku albo Instagramie. Im więcej osób zobaczy, tym więcej kobiet nauczymy ${ }^{32}$ ". Tym sposobem zdjęcia nagich piersi kobiet pojawiały się na popularnych portalach społecznościowych, lecz po kilku godzinach były z nich usuwane ze względu na obowiązujący na nich regulamin. Użytkownicy mediów społecznościowych nadal jednak je publikowali, gdyż niosły za sobą ważny przekaz. O tę chwilę uwagi zabiegali nadawcy reklamy — o poświęcenie jej na badanie własnych piersi. W przeciwnym razie zmiany mogą zostać zauważone zbyt późno. Ostatecznie kampania zyskała wiele pozytywnych i wspierających akcję komentarzy, dzięki którym Facebook i Instagram zaprzestały usuwania postów z nią związanych ${ }^{33}$.
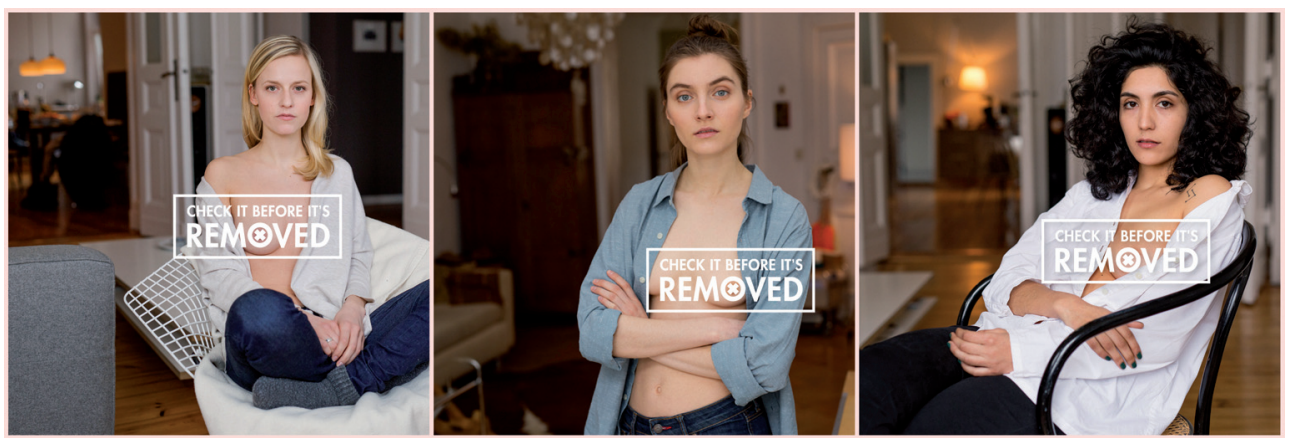

Ilustracja 1. Kampania Check it before it's removed organizacji Pink Ribbon Germany

Źródło: oficjalna strona kampanii, http://www.checkitbeforeitsremoved.com/en/censored/ (dostęp: 7 marca 2019).

\subsection{Kampania \#KnowYourLemons}

Kampania pod hasłem \#KnowYourLemons (tłum. Poznaj swoje cytrynki) to seria viralowych grafik, które dotyczą profilaktyki raka piersi. Przygotowana przez organizację Worldwide Breast Cancer kampania na przykładzie cytryn tłumaczy, jak może wyglądać rak piersi. Dzięki tym kolorowym ilustracjom można dowiedzieć się, że nowotwór piersi to nie tylko guzek, lecz także zaczerwienienie, wgniecenia,

\footnotetext{
32 http://checkitbeforeitsremoved.com/en/uncensored/ (dostęp: 7 grudnia 2016).

33 http://www.kampaniespoleczne.pl/kampanie,3829,zanim_skasuja_zdjecie_piersi (dostęp: 7 grudnia 2016).
} 
widoczne żyły czy delikatna zmiana kształtu piersi (il. 1). Tych kilka prostych zdjęć stanowi o fenomenie i popularności kampanii w sieci. W każdej z nich zawarta jest informacja o symptomach raka oraz postępowaniu w sytuacji jakichkolwiek podejrzeń. Zdaniem twórców użycie tak designerskich środków wyrazu ma za zadanie pomóc w przełamywaniu trzech najczęściej spotykanych barier, które towarzyszą rozmowom o raku piersi: pierwsza $\mathrm{z}$ nich to łączenie kobiecej nagości wyłącznie $\mathrm{z}$ seksem, druga to przełamanie naukowego dyskursu związanego $\mathrm{z}$ rakiem, trzecią jest oswojenie strachu przed tą chorobą ${ }^{34}$.

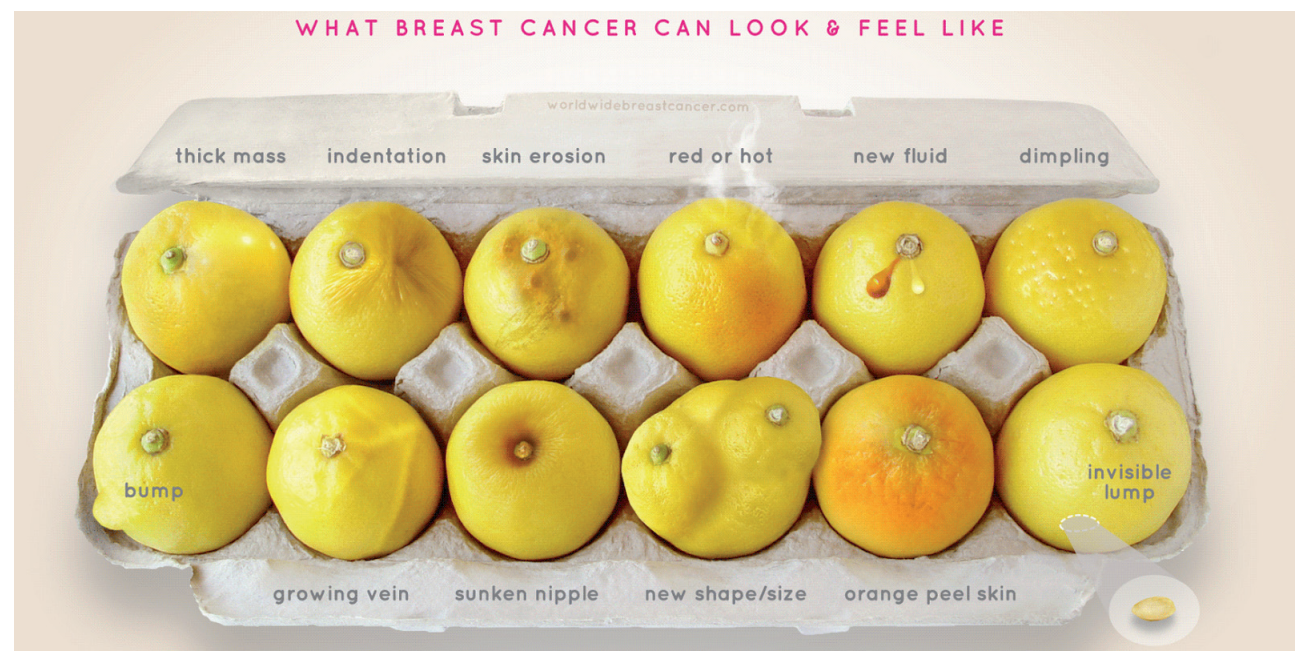

Ilustracja 2. Kampania \#KnowYourLemons organizacji Worldwide Breast Cancer

Źródło: oficjalna strona kampanii, https://knowyourlemons.com/ (dostęp: 7 marca 2019).

\subsection{Kampania Zbieramy na cycki, nowe fryzury i dragi Fundacji Rak'n'Roll}

Zbieramy na cycki, nowe fryzury i dragi — takie hasło promowało jedną z najgłośniejszych kampanii fundacji Rak’n'Roll. Kampania miała swoją premierę w kwietniu 2012 roku, a jej celem było zachęcenie do przekazania 1\% podatku na rzecz fundacji. Akcja obejmowała reklamy w prasie, kinach, radiu, w Internecie oraz działania bezpośrednie w salonach bieliźniarskich, fryzjerskich oraz klubach fitness. Plakaty, które zostały przygotowane $\mathrm{w}$ ramach kampanii, przedstawiały kobiety trzymające karton z odręcznie napisaną prośbą. Twarzami reklamy społecznej były Magdalena Prokopowicz, założycielka fundacji, oraz Joanna Sałyga „Chustka”, podopieczna fundacji, autorka bloga. Kobiety mają na głowach czapki, przez co odbiorcy mają jasność, że zmagają się one z chorobami nowotworowymi. Są jednak uśmiechnięte, pomalowane

34 http://www.kampaniespoleczne.pl/kampanie,3964,knowyourlemons_poznaj_swoje_cytrynki (dostęp: 14 czerwca 2017). 
i nie przypominają znanego obrazu osób cierpiących na raka. Nośne hasło zwracało uwagę na typowe potrzeby kobiet, które walczą z chorobą nowotworową: „Kobietom po chemioterapii potrzebne są peruki, pomoc finansowa potrzebna jest na lekarstwa, których nie finansuje NFZ i Ministerstwo Zdrowia. Rekonstrukcja piersi to zabieg kosztowny"35. Pomysłowy plakat największą popularność zdobył na Facebooku, gdzie stronę promującą kampanię polubiło już ponad półtora tysiąca użytkowników ${ }^{36}$.

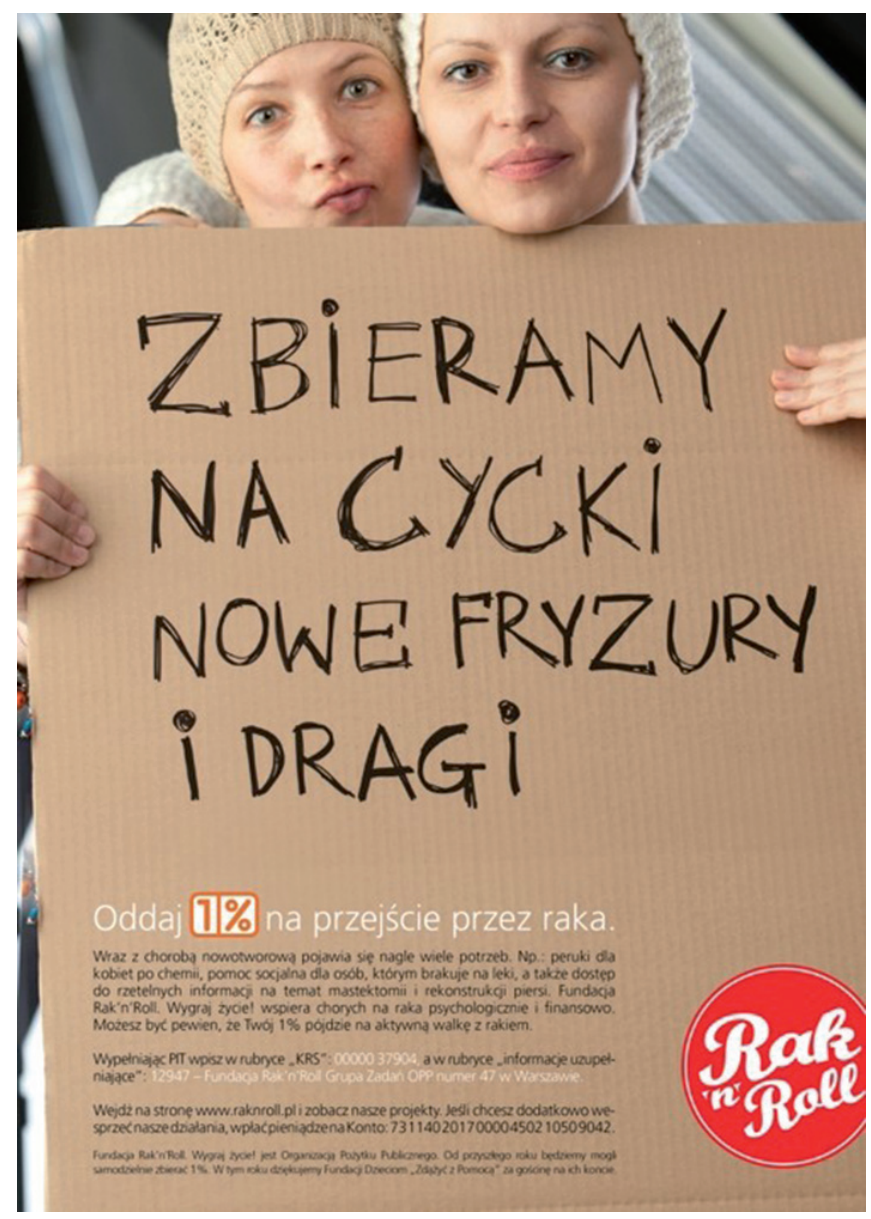

Ilustracja 3. Kampania Zbieramy na cycki, nowe fryzury i dragi fundacji Rak'n'Roll

Źródło: Źródło: Oficjalny profil fundacji Rak'n'Roll, https://www.facebook.com/FundacjaRaknRoll/photos/a$.10155835160615393 / 10155835528085393 /$ ?type=3\&hc_ref=ARS8YRtCJZdulJxxl-dORqffvFg2-Drz3FGURC_fbw_ NYSy2CsPOU_MiqdmGX6527TI (dostęp: 7 marca 2019).

35 http://www.kampaniespoleczne.pl/kampanie,2240,dziewczyny_zbieraja_na_cycki (dostęp: 17 czerwca 2017).

36 https://www.facebook.com/FundacjaRaknRoll/ (dostęp: 17 czerwca 2017). 
Kampania o charakterze fundraisingowym postawiła na przewrotny komunikat umożliwiający realizację założenia fundacji, która w mówieniu o chorobie przeciwstawia się typowej, stereotypowej i smutnej komunikacji. Nadawcom zależało, aby kreacja „nie wywoływała częstego przy takich przekazach przygnębienia, ale zarażała pozytywną energią, stanowiącą fundament działalności Rak'n'Roll”37. Zdaniem Wiesława Gałązki, specjalisty do spraw public relations i etyki, kampania

to bardzo dobry pomysł, język „mediów społecznościowych” trafia, zwłaszcza do młodych ludzi. Dlatego gratuluję hasła jego autorom, a samej fundacji gratuluję odwagi. Pamiętajmy jednak, że dla kobiet chemioterapia, amputacja piersi to wielkie nieszczęście. Dlatego powinniśmy należycie pokazywać, jakie jest tło problemu, czego akcja tak naprawdę dotyczy. Wszystko po to, by sformułowaniami typu „cycki” i „dragi” nikt, zwłaszcza cierpiące kobiety, nie poczuł się dotknięty. Z drugiej strony, gdyby hasło było grzeczne, nie zwrócilibyśmy na nie uwagi ${ }^{38}$.

\section{Podsumowanie}

Choć niestandardowe formy reklamy coraz częściej znajdują zastosowanie w komunikacji o zdrowiu, to wciąż trudno je analizować na poziomie metodologicznym niełatwo je mierzyć i badać. Należy jednak zauważyć, że są pełnowartościową i równoległą płaszczyzną dla tradycyjnych nośników reklamy społecznej i przyczyniają się do zwiększenia jej zasięgu. Warto pamiętać, że prasa nie została wyparta przez Internet, a telewizja nie wyparła radia. Także nowe narzędzia (ambient) nie wyprą starszych. Biorąc pod uwagę, że nowe media można definiować przez pryzmat hybrydyzowania poprzedników, reklama ambientowa w pewnych obszarach ma szansę osiągać cele skuteczniej od pozostałych środków komunikacji. Działania niestandardowe są niepowtarzalne, trafiają do odbiorcy, zostają zauważone, następnie znikają. Ważny w nich jest element zabawy i humoru, wzbudzanie pozytywnych emocji u odbiorców.

Zaprezentowane kampanie to wynik rozwoju technologii. Pojawienie się Internetu przyczyniło się do powstania nowych platform porozumiewania się, między innymi za pomocą narzędzi mediów społecznościowych. Kreatywność kampanii to wynik często możliwości, a czasami (jak w wypadku akcji Check it before it’s removed) ich braku w komunikacji za pośrednictwem mediów społecznościowych. Niemniej Internet, zwłaszcza umieszczanie informacji na temat kampanii, czy to $\mathrm{w}$ formie plakatu czy wideo, wspomaga utrwalanie informacji o akcji, jej idei. W ten sposób użytkownicy życia społecznego mogą ocenić działania fundacji lub innych podmiotów - dając temu wyraz w postaci polubienia czy skomentowania treści kampanii

37 http://www.wirtualnemedia.pl/artykul/kampania-zbieramy-na-cycki-nowe-fryzury-i-dragipodbija-internet\# (dostęp: 17 czerwca 2017).

38 http://www.tvp.info/6948802/ludzie/chore-na-raka-zbieraja-na-cycki-i-dragi/ (dostęp: 17 czerwca 2017).

Dziennikarstwo i Media 9, 2018

(C) for this edition by CNS 
w mediach społecznościowych. Niezwykle ważna jest też obecność prozdrowotnych kampanii w miejscu, gdzie młodzi ludzie koncentrują się wyłącznie na rzeczach przyjemnych, gdzie szukają rozrywki, często zapominając o codzienności ${ }^{39}$. Dodatkowo umieszczanie reklamy społecznej w Internecie, zwłaszcza za pomocą nowoczesnych narzędzi komunikacji, nierzadko przybiera formę działań wirusowych, w których to użytkownicy przekazują sobie treści związane z kampanią — niejednokrotnie decydując o jej dalszym powodzeniu. Wytłumaczeniem tych praktyk jest struktura reklamy, element, który sprawia, „że w konsumencie pojawia się swego rodzaju napięcie psychologiczne, możliwe do rozładowania tylko poprzez podzielenie się informacją na temat tej reklamy z innymi osobami"40.

Wszystkie z zaprezentowanych możliwości ambient mediów nie pozostają obojętne dla komunikacji o raku. Choroby nowotworowe, przede wszystkim tak zwane nowotwory kobiece, jeszcze do lat siedemdziesiątych XX wieku stanowiły temat tabu $\mathrm{w}$ dyskursie społecznym, mocno stygmatyzując przede wszystkim osoby chorujące ${ }^{41}$. I choć ostatnie lata wskazują na wiele pozytywnych zmian w mówieniu o raku, okazuje się, że mają one związek tylko z niektórymi nowotworami i tylko w konkretnych sytuacjach. $Z$ ankiety przeprowadzonej w 12 krajach wynika, że 18-49\% ogółu społeczeństwa uznaje, iż osoby z rozsianym rakiem piersi nie powinny rozmawiać o tym z nikim, poza swoim lekarzem prowadzącym. „Co ciekawe, wśród badanych krajów europejskich w Polsce odnotowano najwyższy odsetek zwolenników ukrywania choroby - aż 33\% respondentów uznało, że o zaawansowanej chorobie nowotworowej należy milczeć" ${ }^{42}$. Kolejny problem to charakter kampanii dotyczących raka piersi. Większość reklam społecznych, korzystających z tradycyjnych nośników, prezentuje temat emocjonalnie, próbując wystraszyć odbiorcę, zmusić go do podjęcia określonych kroków. Inaczej problem prezentowany jest za pomocą ambientu. Przedstawione reklamy swoją komunikację opierały przede wszystkim na humorze, przewrotności, zabawie słowem. Były blisko odbiorcy, tak jak możliwość zachorowania. Tego rodzaju komunikaty, angażujące, zaskakujące odbiorcę, często oddalonego od problemu, pokazują, że z pewnymi tematami należy się oswoić, wejść w dialog, zrozumieć, a czasem nawet ośmieszyć - by przestał być dla nas problemem.

39 D. Burczyc, Reklama na zdrowie. Nowy wymiar kampanii społecznych i ich rola w ksztaltowaniu postaw prozdrowotnych, [w:] Język a media. Zjawiska komunikacyjne we współczesnych mediach, red. B. Skowronek, E. Horyń, A. Walecka-Rynduch, Kraków 2015, s. 221.

40 N. Hatalska, Cząstki przyciagania..., s. 13.

41 http://gazetalekarska.pl/?p=24152 (dostęp: 17 czerwca 2017).

42 Ibidem. 


\section{From lemons to new hairstyles and drugs, that is, how to communicate about cancer in times of inattention}

Summary

The capabilities of ambient media presented in the article are analysed with regard to possible applications in communicated information about cancer. Although there have been a lot of positive changes in talking about cancer, it turns out that they are linked only to some cancers and only to specific situations. Most social advertisements using traditional media present the topic emotionally, trying to scare their addressees to force them to take specific steps. The problem is presented differently by ambient media. Communication in the analysed advertisements was based primarily on humour, paradox, puns. The advertisements were close to their audience, just as the disease itself is today. Such messages, involving, surprising their addressees, who are sometimes far away from the problem, show that some topics need getting used to, need dialogue, often even need to be ridiculed - to cease to be a taboo. 